\begin{tabular}{|c|c|c|}
\hline$W_{\text {INESEG }}$ & $\begin{array}{l}\text { INTERNATIONAL } \\
\text { ENGINEERING, } \\
\text { SCIENCE AND } \\
\text { EDUCATION } \\
\text { GROUP }\end{array}$ & $\begin{array}{l}\text { International Journal of Health Services Research and Policy } \\
\text { (2019) 4(1): 11-21 } \\
\text { Published online April, } 2019 \text { (http://dergipark.gov.tr/ijhsrp) } \\
\text { doi: } 10.23884 / \text { ijhsrp.2019.4.1.02 } \\
\text { e-ISSN: 2602-3482 } \\
\begin{array}{l}\text { Received: February 12, } 2019 \quad \text { Accepted: March 11, } 2019 \\
\text { Submission Type: Research Article }\end{array}\end{array}$ \\
\hline
\end{tabular}

\title{
HEALTHY LIFE-STYLE BEHAVIOURS AND EFFECTING FACTORS OF FINAL YEAR STUDENTS ATTENDING TO TWO DIFFERENT MEDICINE FACULTIES
}

\author{
Bülent ASMA ${ }^{1}$, Süreyya Yiğitalp RENÇBER ${ }^{2}$, Sinemis ÇETİN DAĞLI ${ }^{3}$, Ali CEYLAN $^{4}$ \\ ORCID: 0000-0003-3453-0918 ORCID: 0000-0003-2812-7110 ORCID:0000-0001-9419-4667 \\ ORCID: 0000-0002-3446-7640
${ }^{1}$ Van Yüzüncüyıl University School of Physical Education and Sports
${ }^{2}$ Batman University School of Health
${ }^{3}$ Van Yüzüncüyıl University Medicine Faculty
${ }^{4}$ Dicle University Medicine Faculty
Corresponding author; aliceylan06@gmail.com

\begin{abstract}
This study was carried out to determine and compare the Lifestyles of final year medicine faculty students attending two different universities. The population of this descriptive type study consists of final year students attending Dicle University Medicine Faculty (DUMF) and Van Yüzüncüyll University Medicine Faculty (YYUMF). In 2018-2019 academic year, 166 and 84 intern students are attending to DUMF and YYUMF, respectively; hence, through this number, it is aimed to reach all population. In DUMF, 160 and in YYUMF, 62 were contacted. The students were informed; and they confirmed the consent form and a questionnaire containing descriptive information arranged by Walker. Turkish validity and reliability survey, Healthy Lifestyle Behavioural Scale, was carried out by Bahar et al. in 2008; and the students were given "Healthy Lifestyle Behavioural Scale II" (HLSBS-II), and they were asked to respond the questions. The mean of total scores of HLSBS in

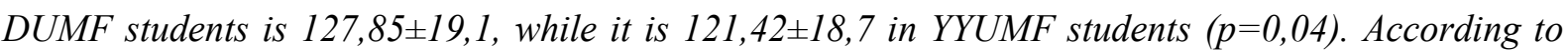
sub groups of HLSBS, the scores that the students gained are as follows: The mean in health

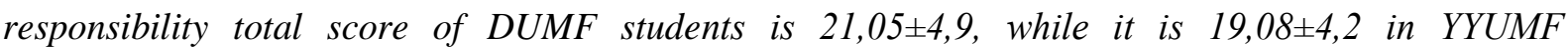
students $(p=0,007)$. The mean in physical activity total score of DUMF students is $16,42 \pm 4,9$, while it is 17,54 4,6 in YYUMF students ( $p=0,123)$. The mean in nourishment total score of DUMF students is

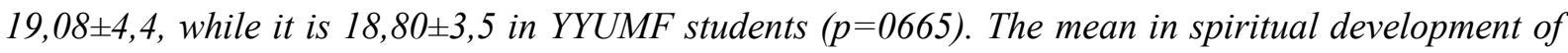

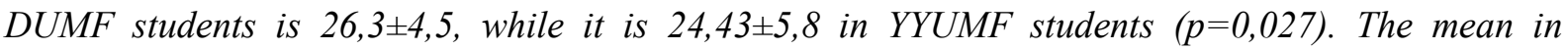

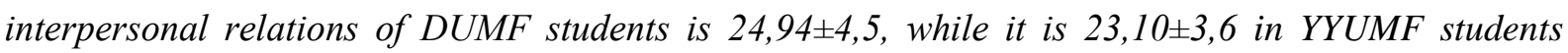

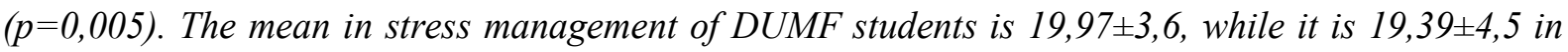
YYUMF students $(p=0,370)$. Total HLSBS score of the students whose family income is good is $130,85 \pm 17,5$, while the total HLSBS score of the ones whose family income is bad is $113,76 \pm 18,8(p=0,004)$. While the total score of physical activity according gender is 17,52 $\pm 4,9$ for men which is higher than women with 15,39 $3,8(p=0,001)$, inter individual relation total point is
\end{abstract}


higher with women $(25,3 \pm 4,5)$ than man $(23,91 \pm 4,2)(p=0,001)$. The fact that the medicine faculty students should lead healthy lifestyle behaviour is important due to the fact that they make a role model for not only themselves but for the society as well. It is thought-provoking that while in normal circumstances 204 score can be obtained from the scale, medicine faculty intern students have received an average of 127,85 score in HLSBS-II; and while in normal condition, it is possible to get 32 scores in the physical activity sub group; medicine students have received only 16,42 score. In order to make the individuals adopt healthy Lifestyle, the earlier the individuals are provided with education and opportunities, the healthier they will be.

Key words: Healthy Lifestyle Behavioural Scale, spiritual development, stress management, physical activity, medical students.

\section{Introduction}

Health understanding of our age aims to protect, continue and develop the health of the society. Healthy Lifestyle is defined as individual's controlling all behaviours which may influence his/her health and his choosing and arranging the daily activities appropriate for his/her health status [1]. Walker, Sechrit and Pender defined Healthy Lifestyle Behaviours (HLSB) as "multi-dimensional model of self-starting activities, perceptions serving to protect and improve the health level, realizing oneself as completion of individuality.'[2]. The individual, who convert these behaviours into attitudes can not only protect his/her health but also continue her healthy status and also he/she can improve his/her health status to a better level. According to WHO data, the reason for $70-80 \%$ of the deaths in underdeveloped countries and $40-50 \%$ of the deaths in developed countries is the behaviours emerging from the life-styles of the individuals [3].

In Ottawa Charter (Ottawa Charter, 1986), one of the universal declarations about protection and improvement of health, improving health is defined as "it is the process of increasing the individuals control over their health and improving their health status"; therefore, improving health has been removed to be a responsibility belonging only to health sector, and thus preconditions for health and health improving policy tools have been established[4].

Improving health aims the betterment of general health status of the individual. However, healthy Lifestyle behaviours contribute to the improvement of health. The achievements obtained by internalizing of the healthy Lifestyle behaviours provide the individuals with consciousness that it is their responsibility to improve their Lifestyle and protect their health. As a result, individuals achieve health protecting and improving behaviours by avoiding risky behaviours that are or may be present in their own lives [5]. It is necessary that individuals be aware of health improving behaviours to convert health improving behaviours into wanted behaviours, and keep them under control, and make these behaviours their Lifestyle by sustaining them. The individual who change these behaviours into practice can not only continue his/her well-being but also carry his/her health status to a better level [6].

In a society, individuals pay importance to health staff in particularly their health protecting behaviours and adopt them as role models. On the other hand, one of the most important missions of health staff working at first stage health services in our country is to protect, improve the health of the society and provide the individuals with healthy Lifestyles [7]. For this reason, health staff primarily should adopt and practise health protecting and improving behaviours. Within this context, it essential 
to evaluate the health Lifestyle behaviours of health employees; and that they should be developed wherever they have deficiencies [6].

Healthy Lifestyle Behaviours Scale (HLSBS) was developed by Walker, Sechrist and Pender to test health-improving model [8]. This tool measures health improving behaviours in relation with individual healthy Lifestyle. The scale, which has 6 sub-groups such as self-realization, health responsibility, physical activity, nourishment, interpersonal relation and stress management, consists of 48 items. In 1995, 4 items were added to the scale, so the items of the scale turned out to be 52 . Each sub-group can be used independently. The total score of the scale gives the score of healthy Lifestyle behaviours [9]. The validity and reliability of HLSBS was performed by Esin in Turkey [10]. For total HLSBS, Cronbach Alpha consistency coefficient was found to be 0,91.

Self-Realization Sub-Group determines life aims and self-realization ability of the individual and how much he/she knows and satisfies himself/herself.

Health Responsibility Sub-Group determines the responsibility level of the individual over his/her health and to what extent he/she deals with it.

Physical Activity Sub-Group shows to what extent the physical activities, as an inevitable element of healthy life, are practised by the individual.

Nourishment Sub-Group determines the individual's choosing and arranging his/her meals and the changes in his/her food selection.

Interpersonal Sub-Group determines the communication and continuity level of the individual with his/her close environment.

Stress Sub-Group determines the individual's recognition level of stress sources and stress control mechanisms.

All items of Healthy Lifestyle behaviours scale are positive. For respond "Never" score is 1, for respond "Sometimes" score is 2, for respond "Often" score is 3, for respond "Regularly" score is 4 point is given. The lowest score for all questions of the scale is 52, while the highest is 208 .

This study was carried out in order to determine and compare the healthy Lifestyle behaviours of the final year students attending to the medicine faculties of two different universities.

\section{Method}

The population of this study, which is in the sectional type, is composed of final year intern students attending Dicle University Medicine Faculty (DUMF) and Van Yüzüncüyıl University Medicine faculty (YYUMF). In 2018-2019 academic year, 166 and 84 intern students are attending DUMF and YYUMF, respectively. Therefore, by this way, it is aimed to reach all population of the study. In DUMF, 160(160/166) and in YYUMF, 62(62/84) students were contacted. The students were given a consent form. Together with this form, they were given a questionnaire containing descriptive information. Afterwards, the students were given and wanted to respond "Healthy Lifestyle Behaviours Scale II" (HLSBS-II), which was arranged by Walker, and whose Turkish validity and reliability investigation was performed in 2008. The participants who did not want to join in the survey and who did not fill in the descriptive information form and HLSBS-II questionnaire completely were excluded (total 28 student).

HLSBS-II is composed of 52 questions and six sub-groups including health responsibility (9 questions), physical activity (8 questions), nourishment (9 questions), spiritual development (9 
questions), interpersonal relations (9 questions) and stress management (8 questions). The scale grading is in 4 Likert type, from this scale minimum 52 score and maximum 208 score can be attained. In the statistical data analyses, the percentage distribution of sectional data and means of constant data are calculated; and in chi-square and independent groups, $t$ test is employed; and the means are given with standard deviation (Mean $\pm \mathrm{SD}$ ), $\mathrm{p}<0.05$ is evaluated as statistical significance.

\section{Findings}

The fact that medicine faculty students enjoy healthy Lifestyle behaviours is significant since they make models for the society. This study was conducted with the participation of final year students (interns) receiving education at Dicle University (DUMF) and Van Yüzüncü Yıl University Medicine faculties (YYUMF). The age average of DUMF students was found to be $24,6 \pm 1,6$ $(\mathrm{p}=0,152)$ and the height average $172,4 \pm 7,7(0,329)$ and the weight average $69,9 \pm 11,3(0,7519)$; likewise, it turned out to be $25,9 \pm 4,5,171,3 \pm 7,6$ and $69,3 \pm 12,5$ with YYUMF students, respectively.

In table 1, some of the demographical properties of the participants are given. Accordingly, $64,4 \%$ of DUMF students are male, while this rate is 59,7\% with YYUMF students. While 65,6\% of DUMF students are with their families; and 23,1\% live in student house; and 11,3\% accommodate in hostel, the rates for YYUMF students are 36,1\%, 33,9\% and 32,8\% ( $\mathrm{p}=0,001)$, respectively. According to their own words, the family economic status of DUMF students is $20,6 \%$ good, $73,8 \%$ medium and $5,6 \%$ bad, while the rates for YYUMF students are 19,4\%, 71,0 and 9,7\% ( $\mathrm{p}=0,56)$, respectively.

The education status of the students' parents was investigated. Of DUMF students' mothers, $47,5 \%$ have not finished any school, 31,9\% are primary school graduates, 11,9\% are high school graduates and $8,8 \%$ are university graduates, while the rates for YYUMF students' mothers are $43,5 \%, 29,0 \%$, $17,7 \%$ and $9,7 \%$, respectively. As to fathers' education status, Of DUMF students' fathers, $23,8 \%$ have not finished any school, 23,1\% are primary school graduates, 31,3\% are high school graduates and $21,9 \%$ are university graduates, while the rates for YYUMF students' fathers are 12,9\%, 33,9\%, $25,8 \%$ and $27,4 \%$, respectively.

$58,1 \%$ of DUMF students have never smoked and 33,1\% regularly smoke. On the other hand, the percentages for YYUMF students are 55,7\% and 27,9\% ( $\mathrm{p}=0,24)$, respectively.

The Height-Weight-Index (HWI) of the students were investigated, according to the measurements, Of DUMF students, $2,5 \%$ were found to be thin, $70,6 \%$ normal weight and $26,9 \%$ fat, while no obese students were found. On the other hand, the measurements for YYUMF turned out to be 3,4\%, 67,2\%, 25,9 , respectively. Obese rate was 3,4\% (2 students).

Table 1. Dispersion of some demographic properties participating in the investigation

\begin{tabular}{|c|c|c|c|c|c|c|c|c|}
\hline \multirow[t]{2}{*}{ Property } & & DUMF & & $\begin{array}{l}\text { YYUM } \\
\text { F }\end{array}$ & & Total & & \\
\hline & & $\begin{array}{l}\text { Numbe } \\
\mathbf{r}\end{array}$ & $\%$ & $\begin{array}{l}\text { Numbe } \\
\mathbf{r}\end{array}$ & $\%$ & $\begin{array}{l}\text { Numbe } \\
r\end{array}$ & $\%$ & $\mathbf{P}$ \\
\hline \multirow[t]{3}{*}{ Gender } & M & 103 & 64,4 & 37 & 59,7 & 140 & 63,1 & 0,515 \\
\hline & $\mathbf{F}$ & 57 & 35,6 & 25 & 40,3 & 82 & 36,9 & \\
\hline & Total & 160 & 100,0 & 62 & 100,0 & 222 & 100,0 & \\
\hline \multirow[t]{2}{*}{ Residence } & Family & 105 & 65,6 & 22 & 36,1 & 127 & 57,5 & 0,000 \\
\hline & Hostel & 18 & 11,3 & 20 & 32,8 & 38 & 17,2 & \\
\hline
\end{tabular}




\begin{tabular}{|l|l|l|l|l|l|l|l|l|}
\hline & Student House & 37 & 23,1 & 19 & 31,1 & 56 & 25,3 & \\
\hline $\begin{array}{l}\text { Family } \\
\text { Income } \\
\text { Status }\end{array}$ & Good & 33 & 20,6 & 12 & 19,3 & 45 & 20,2 & $\mathrm{P}=0,557$ \\
\hline & Medium & 118 & 73,8 & 44 & 71,0 & 162 & 73,0 & \\
\hline & Bad & 9 & 5,6 & 6 & 9,7 & 15 & 6,8 & \\
\hline $\begin{array}{l}\text { Smoking } \\
\text { Case }\end{array}$ & Never tried & 93 & 58,1 & 34 & 55,7 & 127 & 57,5 & $\mathrm{P}=0,246$ \\
\hline & Still smoking & 53 & 33,1 & 17 & 27,9 & 70 & 31,6 & \\
\hline & Used to smoke & 14 & 8,8 & 10 & 16,4 & 24 & 10,9 & \\
\hline $\begin{array}{l}\text { Mother's } \\
\text { Education }\end{array}$ & $\begin{array}{l}\text { No School } \\
\text { finished }\end{array}$ & 76 & 47,4 & 27 & 43,6 & 103 & 46,4 & $\mathrm{P}=0,694$ \\
\hline & $\begin{array}{l}\text { Primary School } \\
\text { Graduate }\end{array}$ & 51 & 31,9 & 18 & 29,0 & 69 & 31,1 & \\
\hline & $\begin{array}{l}\text { High School } \\
\text { Graduate }\end{array}$ & 19 & 11,9 & 11 & 17,7 & 30 & 13,5 & \\
\hline & $\begin{array}{l}\text { University } \\
\text { Graduate }\end{array}$ & 14 & 8,8 & 6 & 9,7 & 20 & 9,0 & \\
\hline $\begin{array}{l}\text { Father's } \\
\text { Education }\end{array}$ & $\begin{array}{l}\text { No School } \\
\text { Finished }\end{array}$ & 38 & 23,8 & 8 & 12,9 & 46 & 20,7 & $\mathrm{P}=0,136$ \\
\hline & $\begin{array}{l}\text { Primary School } \\
\text { Graduate }\end{array}$ & 37 & 23,1 & 21 & 33,9 & 58 & 26,1 & \\
\hline & $\begin{array}{l}\text { High School } \\
\text { Graduate }\end{array}$ & 50 & 31,3 & 16 & 25,8 & 66 & 29,8 & \\
\hline & $\begin{array}{l}\text { University } \\
\text { Graduate }\end{array}$ & 35 & 21,8 & 17 & 27,4 & 52 & 23,4 & \\
\hline & Thin & 4 & 2,5 & 2 & 3,4 & 6 & 2,8 & $\mathrm{P}=0,125$ \\
\hline & Normal & 113 & 70,6 & 39 & 67,3 & 152 & 69,7 & \\
\hline & Obez & 0 & 0,0 & 2 & 3,4 & 2 & 0,9 & \\
\hline & & & & & & & & \\
\hline
\end{tabular}

In Table 2, Healthy Lifestyle Behaviour Scale Mean Scores of the students are seen. Accordingly, the total HLSBS score mean of DUMF students is $127,85 \pm 19,1$, while it is $121,42 \pm 18,7$ for YYUMF students $(\mathrm{p}=0,04)$.

The scores that the students obtained according to sub-groups of scale for total score mean of health responsibility is $21,1 \pm 4,9$ for DUMF students, while it is $19,1 \pm 4,2$ for YYUMF students ( $p=0,007$ ). The physical activity total score mean for DUMF students is $16,4 \pm 4,9$, while it is $17,5 \pm 4,6$ for YYUMF students $(\mathrm{p}=0,123)$. The nourishment total score mean for DUMF students is $19,1 \pm 4,4$, while it is $18,8 \pm 3,6$ for YYUMF students $(\mathrm{p}=0,67)$. The spiritual development total score mean for DUMF students is $26,3 \pm 4,5$, while it is $24,4 \pm 5,8$ for YYUMF students $(\mathrm{p}=0,012$ ). The inter-personal relation total score mean for DUMF students is $24,9 \pm 4,5$, while it is $23,1 \pm 3,6$ for YYUMF students ( $\mathrm{p}=0,002$ ). The stress management total score mean for DUMF students is $20,0 \pm 3,6$, while it is $19,4 \pm 4,5$ for YYUMF students ( $\mathrm{p}=0,321)$. 
Table 2. The dispersion of total and sub-group HLSBS scores of the students participating in the study according to their faculties

\begin{tabular}{|c|c|c|c|c|c|c|}
\hline & Faculty & $\mathrm{N}$ & Mean & $\begin{array}{c}\text { Std. } \\
\text { Deviation }\end{array}$ & $\begin{array}{c}\text { Std. Error } \\
\text { Mean } \\
\end{array}$ & $\mathrm{P}$ \\
\hline \multirow{2}{*}{$\begin{array}{l}\text { Total HLSBS } \\
\text { score }\end{array}$} & DUMF & 159 & 127,8553 & 19,09895 & 1,51465 & 0,04 \\
\hline & YYUMF & 49 & 121,4286 & 18,72832 & 2,67547 & \\
\hline \multirow{2}{*}{$\begin{array}{l}\text { Health } \\
\text { responsibility } \\
\text { total }\end{array}$} & DUMF & 160 & 21,0563 & 4,89930 & ,38732 & 0,007 \\
\hline & YYUMF & 59 & 19,0847 & 4,23568 &, 55144 & \\
\hline \multirow{2}{*}{$\begin{array}{l}\text { Physical } \\
\text { activity total }\end{array}$} & DUMF & 160 & 16,4250 & 4,93932 & ,39049 & 0,123 \\
\hline & YYUMF & 62 & 17,5484 & 4,60106 & ,58434 & \\
\hline \multirow{2}{*}{$\begin{array}{l}\text { Nourishment } \\
\text { Total }\end{array}$} & DUMF & 160 & 19,0875 & 4,44022 & ,35103 & 0,667 \\
\hline & YYUMF & 56 & 18,8036 & 3,58998 & ,47973 & \\
\hline \multirow{2}{*}{$\begin{array}{l}\text { Spiritual } \\
\text { Development } \\
\text { Total }\end{array}$} & DUMF & 160 & 26,3375 & 4,51118 & ,35664 & 0,012 \\
\hline & YYUMF & 58 & 24,4310 & 5,85830 & ,76923 & \\
\hline \multirow{2}{*}{$\begin{array}{l}\text { Interpersonal } \\
\text { relations total }\end{array}$} & DUMF & 159 & 24,9434 & 4,50210 & ,35704 & 0,002 \\
\hline & YYUMF & 60 & 23,1000 & 3,64854 & ,47102 & \\
\hline \multirow{2}{*}{$\begin{array}{l}\text { Stress } \\
\text { management } \\
\text { Total }\end{array}$} & DUMF & 160 & 19,9750 & 3,62200 & ,28634 & 0,321 \\
\hline & YYUMF & 61 & 19,3934 & 4,52135 & ,57890 & \\
\hline
\end{tabular}

The scores of HLSBS for gender were calculated; and the results are given in Table 3. In accordance with the scores, The total mean score of HLSBS for males is $126,2 \pm 19,5$, while it is $126,5 \pm 18,6$ for females $(\mathrm{p}=0,911)$. The total mean score of health responsibility for males is $20,2 \pm 4,6$, while it is $21,0 \pm 5,0$ for females $(\mathrm{p}=0,251)$. The total mean score of physical activity for males is $17,5 \pm 5,0$, while it is $15,4 \pm 4,4$ for females $(\mathrm{p}=0,001)$. The total mean score of nourishment for males is $18,8 \pm 4,4$, while it is $19,3 \pm 3,8$ for females ( $\mathrm{p}=0,356$ ). The total mean score of spiritual development for males is $25,6 \pm 4,5$, while it is $26,2 \pm 5,6$ for females $(\mathrm{p}=0,436)$. The total mean score of inter-personal relations for males is $23,9 \pm 4,2$, while it is $25,3 \pm 4,5$ for females $(\mathrm{p}=0,021)$. The total mean score of stress management for males is $19,7 \pm 3,6$, while it is $20,0 \pm 4,4$ for females $(p=0,539)$.

Table 3. The dispersion of total HLSBS and sub-group scores of the students participating in the study according to gender

\begin{tabular}{|c|c|c|c|c|c|c|}
\hline & Gender & $\mathrm{N}$ & Mean & $\begin{array}{c}\text { Std. } \\
\text { Deviation }\end{array}$ & $\begin{array}{l}\text { Std. Error } \\
\text { Mean }\end{array}$ & $\mathrm{P}$ \\
\hline \multirow{2}{*}{$\begin{array}{l}\text { Total HLSBS } \\
\text { score }\end{array}$} & $\mathrm{M}$ & 129 & 126,2248 & 19,52132 & 1,71876 & 0,911 \\
\hline & $\mathrm{F}$ & 79 & 126,5316 & 18,68555 & 2,10229 & \\
\hline \multirow{2}{*}{$\begin{array}{l}\text { Health } \\
\text { responsibility } \\
\text { total }\end{array}$} & $\mathrm{M}$ & 138 & 20,2391 & 4,65849 & ,39656 & 0,251 \\
\hline & $\mathrm{F}$ & 81 & 21,0123 & 5,02617 & ,55846 & \\
\hline \multirow{2}{*}{$\begin{array}{l}\text { Physical } \\
\text { activity total }\end{array}$} & M & 140 & 17,5286 & 4,97250 & ,42025 & 0,001 \\
\hline & $\mathrm{F}$ & 82 & 15,3902 & 4,37940 & , 48362 & \\
\hline Nourishment & $\mathrm{M}$ & 135 & 18,8074 & 4,43947 & ,38209 & 0,356 \\
\hline
\end{tabular}




\begin{tabular}{|c|c|c|c|c|c|c|}
\hline Total & $\mathrm{F}$ & 81 & 19,3580 & 3,85781 & ,42865 & \\
\hline \multirow{2}{*}{$\begin{array}{l}\text { Spiritual } \\
\text { Development } \\
\text { Total }\end{array}$} & $\mathrm{M}$ & 138 & 25,6304 & 4,53547 & ,38608 & 0,436 \\
\hline & $\mathrm{F}$ & 80 & 26,1750 & 5,64066 & 63065 & \\
\hline \multirow{2}{*}{$\begin{array}{l}\text { Interpersonal } \\
\text { relations total }\end{array}$} & $\mathrm{M}$ & 137 & 23,9124 & 4,19291 & ,35822 & 0,021 \\
\hline & $\mathrm{F}$ & 82 & 25,3171 & 4,50481 & ,49747 & \\
\hline \multirow{2}{*}{$\begin{array}{l}\text { Stress } \\
\text { management } \\
\text { Total }\end{array}$} & $\mathrm{M}$ & 139 & 19,6906 & 3,56889 & ,30271 & 0,539 \\
\hline & $\mathrm{F}$ & 82 & 20,0244 & 4,39409 & ,48525 & \\
\hline
\end{tabular}

The HLSBS score means of the students were examined according to their socio-economic status; and the results are given in Table 4. The total mean score of HLSBS for students whose economic status are good is $130,8 \pm 17,5$, while it is $114,5 \pm 18,3$ for the ones whose economic status is bad ( $\mathrm{p}=0,004)$. The mean total of health responsibility for the ones whose economic status good is $20,6 \pm 4,4$, while it is $17,8 \pm 3,8$ for the ones whose economic status is bad ( $\mathrm{p}=0,038)$. The mean total of physical activity for the ones whose economic status good is $18,3 \pm 4,5$, while it is $12,7 \pm 34,1$ for the ones whose economic status is bad $(\mathrm{p}=0,000)$. The mean total of nourishment for the ones whose economic status good is $19,6 \pm 3,9$, while it is $16,5 \pm 3,4$ for the ones whose economic status is bad $(\mathrm{p}=0,010)$. The mean total of spiritual development for the ones whose economic status good is $26,7 \pm 5,6$, while it is $25,5 \pm 5,8$ for the ones whose economic status is bad $(\mathrm{p}=0,487)$. The mean total of interpersonal relations for the ones whose economic status good is $24,8 \pm 4,1$, while it is $20,1 \pm 3,1$ for the ones whose economic status is bad $(\mathrm{p}=0,546)$. The mean total of stress management for the ones whose economic status good is $20,1 \pm 3,1$, while it is $18,2 \pm 4,1$ for the ones whose economic status is $\operatorname{bad}(\mathrm{p}=0,063)$.

Table 4. The dispersion of total HLSBS and sub scores of students participating in the study according to economic status

\begin{tabular}{|c|c|c|c|c|c|c|}
\hline & $\begin{array}{l}\text { Economic } \\
\text { Status }\end{array}$ & $\mathrm{N}$ & Mean & $\begin{array}{c}\text { Std. } \\
\text { Deviation }\end{array}$ & $\begin{array}{c}\text { Std. Error } \\
\text { Mean }\end{array}$ & $\mathrm{P}$ \\
\hline \multirow{2}{*}{$\begin{array}{l}\text { Total HLSBS } \\
\text { score }\end{array}$} & Good & 41 & 130,8537 & 17,48651 & 2,73093 & 0,004 \\
\hline & Bad & 14 & 114,5000 & 18,26619 & 4,88185 & \\
\hline \multirow{2}{*}{$\begin{array}{l}\text { Health } \\
\text { responsibility } \\
\text { total }\end{array}$} & Good & 44 & 20,5682 & 4,36369 & ,65785 & 0,038 \\
\hline & Bad & 15 & 17,8667 & 3,85202 & 99459 & \\
\hline \multirow{2}{*}{$\begin{array}{l}\text { Physical } \\
\text { activity total }\end{array}$} & Good & 45 & 18,2889 & 4,50062 & 67091 & 0,000 \\
\hline & Bad & 15 & 12,8667 & 4,13809 & 1,06845 & \\
\hline \multirow{2}{*}{$\begin{array}{l}\text { Nourishment } \\
\text { Total }\end{array}$} & Good & 42 & 19,5952 & 3,90159 & 60203 & 0,010 \\
\hline & $\mathrm{Bad}$ & 14 & 16,5000 & 3,36841 & ,90024 & \\
\hline \multirow{2}{*}{$\begin{array}{l}\text { Spiritual } \\
\text { Development } \\
\text { Total }\end{array}$} & Good & 43 & 26,7209 & 5,60750 & ,85514 & 0,487 \\
\hline & $\mathrm{Bad}$ & 15 & 25,5333 & 5,82932 & 1,50512 & \\
\hline \multirow{2}{*}{$\begin{array}{l}\text { Interpersonal } \\
\text { relations total }\end{array}$} & Good & 44 & 24,8182 & 4,09352 & ,61712 & 0,546 \\
\hline & $\mathrm{Bad}$ & 15 & 24,0000 & 5,58058 & 1,44090 & \\
\hline \multirow{2}{*}{$\begin{array}{l}\text { Stress } \\
\text { management }\end{array}$} & Good & 45 & 20,0889 & 3,08090 & ,45927 & 0,063 \\
\hline & $\mathrm{Bad}$ & 15 & 18,2000 & 4,05674 & 1,04745 & \\
\hline
\end{tabular}




\begin{tabular}{|l|l|l|l|l|l|l|}
\hline Total & & & & & \\
\hline
\end{tabular}

\section{Discussion}

One of the most significant missions that submit responsibility at the first stage health services is to preserve and improve health of society and to provide the individuals with healthy Lifestyle behaviours[7]. In the education programs for society and especially in order to inform the individual, family and society in improving health, and to be able to perform the behavioural change, various methods are utilized. One of these is to be a model. Because of this, starting with the doctors working at first stage health centres, health professionals should primarily adopt health protecting and improving behaviours and then apply them in their lives. In this study, healthy Lifestyle behaviours of candidate doctors, who will make up the basic human power in conducting health services at first stage health centres, were evaluated during their internship period before they start to work. The students of two medicine faculties located in the Eastern and South-eastern regions of our country have similar defining properties such as age, gender, height average, economic status, parents' education status. However, according to the students' accommodation properties, while of the DUMF students $65,6 \%$ reside with their families, $23,1 \%$ live in student house, $11,3 \%$ stay at hostel, the rates for YYUMF students are $36,1 \%, 33,9 \%$ and $32,8 \%$, respectively $[p=0,001]$. This difference can be connected with the fact that the province of Van has less population and there are not any medicine faculty in the neighbouring towns, and the students therefore prefer this medicine faculty.

The mean total HLSBS scores was found to be 127, 85 $\pm 19,1$ for DUMF students, while it was $121,42 \pm 18,7$ for YYUMF students $(\mathrm{p}=0,04)$. In literature, there are a number of studies related to the health workers and the students having medical education and training. The most recent study is the study carried out by Nacar [11]. This study is a multi-centred study that he performed in medicine faculty students. He found that the HLSBS of first class students of medicine faculty to be 129,2, while the final year students' score was 125,5. In the same study, the HLSBS mean scores of the students according to the faculties they attended were as follows: For Erciyes University students, it was 128.8 \pm 18.6 ; and for Gazi University students, it was 129.4 \pm 18.9 ; and for Konya Seljuk University students, it was $127.7 \pm 17.8$; and for Eskişehir Osmangazi University students, it was 127.3 \pm 18.5 ; and for Ege University students, it was 126.7 \pm 17.2 ; and for Kahraman Maraş Sütçü İmam

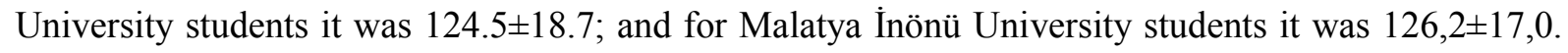
These scores appear to be closer to DUMF scores.

One of other studies related to the students having education and training in the field of health is the one carried out by Kurt [12]. In his study, Kurt found the HLSBS mean score of students attending Nursery and Midwifery department to be 123, $12 \pm 16,51$. In his study, Şen [13] found $118,01 \pm 21,0$ score with students of Health Services Vocational School. In his study, Cihangiroğlu [14] found $121,75 \pm 18,86$ score with students of Health School.

In the studies carried out with Health Workers, Güner [15], in his study, found that total mean

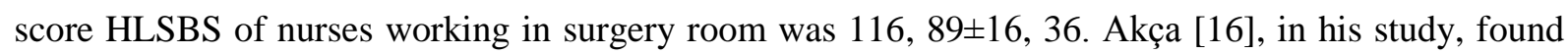
that total mean score HLSBS of academicians was 133, 29 \pm 18 , 16. Elvan and Türkol [1], in their study, found it to be 116,31 $\pm 17,80$. Gündoğdu and Güler [17], in their study performed with health workers working first stage health centre, found it to be $128 \pm 21,3$. The results vary between 116 and 133. These scores were compared with the scores students according to sub groups of the scale. 
The sub group, health responsibility, determines at what levels the individual participates in his health and the responsibility over his health. In this field, the students can be given 9 points at least and 36 points at most. Health responsibility total score for DUMF students was found to be $21,1 \pm 4,9$, while it was $19,1 \pm 4,2$ for YYUMF students ( $\mathrm{p}=0,007$ ). The total score of health responsibility for males turned out to be $20,2 \pm 4,66$, while it was $21,0 \pm 5,02$ for females $(\mathrm{p}=0,251)$. While the score for the ones whose family income was low appeared to be $20,6 \pm 4,4$, the score for the ones whose family income was bad was found to be $(17,9 \pm 3,85)(\mathrm{p}=0,038)$. The differences between the groups are considerably significant. The total score of health responsibility in the other studies are as follows: In Güner's study it is found as $22,5 \pm 5,03$, in Kurt's study it is $19.9 \pm 4.21$, in Elvan's study it is $18.0 \pm 3.47$ and in Şen's study it is $18,8 \pm 3,9$.

Physical Activity Sub Group shows at what level physical activity applications, inevitable aspects of healthy life, are practised by individuals. There are 8 questions in this sub group, and the participants obtain scores between 8 and 32. The total score was found to be $16,4 \pm 4,9$ with DUMF students, while it was $17,5 \pm 4,6$ with YYUMF students. The score was $17,5 \pm 4,97$ with male students, while it was $17,5 \pm 4,6$ with female students $(\mathrm{p}=0,001)$. The score was found to be higher with the ones whose economic status was good than those whose economic status was bad with $18,3 \pm 4,50$ and $15,4 \pm 4,7$, respectively[p=0,000].In the study which was carried out by Nacar, the score about the abovementioned sub group with medicine students was found out to be $16,0 \pm 4,4$, while in Güner's study, the mean score was rather low with $8,0 \pm 2,26$, while in Kurt's study, it was $19.9 \pm 4.21$, and in Türkol's study, it was 14.7 \pm 4.24 , and in Özveren's study, it was 17,4 $\pm 5,16$, and finally, in Şen's study, it was $15,2 \pm 4.7$. Gender, economic status and profession are exhibited to be the factors effecting Healthy Lifestyle in several studies $(18,19,20,21)$.

Nourishment Sub Group: It determines the changes in individual's choosing and arranging his meals and choosing his food. The participants receive between 9 and 32 points out of 9 questions. Total scores for nourishment was found to be $19,1 \pm 4,4$ for DUMF students, while it was $18,8 \pm 3,6$ for YYUMF students $(\mathrm{p}=0,067)$. The scores about the same sub group is $18,8 \pm 4,43$ for males, while it is $19,4 \pm 3,85$ for females $(p=0,356)$. On the other hand it is $19,6 \pm 3,90$ for the ones whose economic condition is good, while it is $16,5 \pm 3,69$ for the ones whose economic condition is $\operatorname{bad}(\mathrm{p}=0,010)$. This difference is considerably significant. In the literature, there are several values for the same sub group such as in the study conducted by Kurt it is $19,0 \pm 3,68$, and by Türkol, it is $19,1 \pm 3,72$, and by Şen, it is $18,46 \pm 4,1$. That the economic status is good positively affects the decisions about nourishment.

Spiritual Development Sub Group: This sub group determines the individual's living style, his ability to improve himself, and how much he knows himself and if he can please himself. In this section, the students can get 9 points at least and 36 points at most. Spiritual development total score was found as $26,3 \pm 4,5$ with DUMF students, while it was $24,4 \pm 5,8$ with YYUMF students( $\mathrm{p}=0,012$ ). The scores for the same sub group is $25,6 \pm 4,5$ for males, while it is $26,2 \pm 5,6$ for females, and $26,7 \pm 5,6$ for students with good economic status, while it is $25,5 \pm 5,8$ for students with bad economic status, which is found trivial. In other studies, for example, Nacar found $26,5 \pm 4,5$ total score mean with

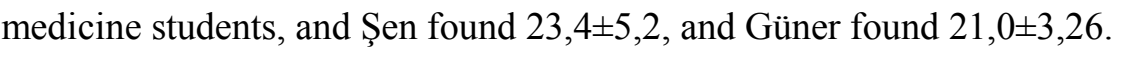


Stress Management Sub Group: It determines the level of stress sources and stress control mechanisms of individual. In this section the participants can get 8 points at least and 32 points at most. The total score mean of stress management for DUMF students was found to be $20,0 \pm 3,6$, while it was $19,4 \pm 4,5$ for YYUMF students( $\mathrm{p}=0,321)$. The score was found as $19,7 \pm 3,57$ for males and $20,02 \pm 4,39$ for females; and $20,1 \pm 3,08$ for ones with good economic status and $20,01 \pm 3,08$ for the ones with bad economic status $(\mathrm{p}=0,063)$. In other studies, the scores are as these: Şen: $17,4 \pm 3,5$, and

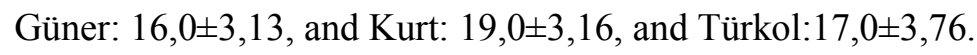

Interpersonal Relation Sub Group: It determines the individual's contact with his close friends and the level of constancy of this communication. In this section, the participant can get 9 points at least and 36 points at most. The total score mean of interpersonal relations is $24,9 \pm 4,5$ for DUMF students, while it is $23,1 \pm 3,6$ for YYUMF students ( $\mathrm{p}=0,002)$. According to study, for the same sub group, the score for male participants is $23,9 \pm 4,19$, while it is $25,3 \pm 4,5$ for female participants; and it is $24,8 \pm 4,09$ for the ones with good economic status, while it is $24,0 \pm 5,58$ for the ones with bad economic status. The mean scores received for interpersonal relations in other studies are these: In the study carried out by Nacar, it is $25,1 \pm 4,1$, and In the study carried out by Şen, it is $23,4 \pm 5,2$, and In the study carried out by Kurt, it is $24,4 \pm 4,20$, and In the study carried out by Türkol, it is $23,7 \pm 3,73$, and In the study carried out by Güner, it is $21,0 \pm 3,26$.

\section{Result and Suggestions}

It is important that medicine faculty students carry on healthy Lifestyle owing to the fact that they make role model for the society. While it is possible to attain 204 total score from HLSBS-II, the medicine faculty intern students have obtained an average of 127,85 score, and while it is possible that they can achieve 32 score from physical activity sub group, they have received 16,42 score. This case is thought provoking. In order to adopt healthy Lifestyle behaviour as our Lifestyle, the earlier age we start and provide opportunities, the healthier the society will be.

\section{References:}

[1]. Türkol, E., Güneş, G., "The Healthy Lifestyle Behaviours of Assistants Specializing in İnönü University Medicine Faculty Hospital”, Inönü University, Medicine Faculty Journal,19(3),159-66, 2012.

[2]. Ünalan, D., Şenol, V., Öztürk A., et al., "Investigating the Relation between Healthy Lifestyle Behaviours Self-Care Power Levels of Students Attending Health and Social Programs of Vocational Colleges”, Inönü University, Medicine Faculty Journal, 14,101-9, 2007.

[3]. Dickey Janick JJ. "Lifestyle Modifications in the Prevention and Treatment of Hypertension", Endorc Pract, 7(5), 392-9, 2001.

[4]. Ottawa Charter For Health Promotion. (1986). First international conference on Health Promotion Access: 17.02.2006. http://www.who.int/hpr/NPH/docs/ottawa_charter_hp Ottawa,WHO/HPR/HEP/95.1

[5]. Ayaz, S., Tezcan, S., Akınc1, F., "Health İmprovement Behaviours of Nursery School Students. Cumhuriyet University", Journal of Nursery School, 9, 26-34, 2005.

[6]. Yalçınkaya, M., Özer, FG., Karamanoğlu, AY., "Evaluation of Healthy Lifestyle Behaviours with Health Workers", TAF Preventive Medical Bulletin, 6, 409-20, 2007. 
[7]. Dirican, R., Bilgel, N. Public Health, II Edition, Uludağ University Publishing, Bursa. 1993.

[8]. Karadeniz, G., Uçum, EY., Dedli, Ö., Karaağaç, Ö., "Healthy Lifestyle Behaviours of University Students", TAF, Preventive Medical Bulletin, 7, 497-502, 2008.

[9] Rozmus, CL., Evans, R., Wysochansky, M., Mixon, D., "An Analysis of Health Promotion and Risk Behaviors of Freshman College Students in A Rural Southern Setting”, J Pediatr Nurs, 20 (1), 25-33, 2005.

[10]. Esin, MN., “Adaptation of Healthy Lifestyle Behaviours Scale into Turkish”, Nursery Bulletin, 2(45), 87-96, 1999.

[11]. Nacar, M., Baykan, M., Cetinkaya, F., Arslantas, D., Oze,r A., Coskun, Ö., Bati, H., Karaoglu, N., Elmali, F., Yilmazel, G., "Health Promoting Lifestyle Behaviour in Medical Students: a Multicentre Study from Turkey", Asian Pacific Journal of Cancer Prevention, 15(20), 8969-74. 2014. [12]. Kurt AS., "The Relationship between Healthy Lifestyle Behaviours and Health Locus of Control among Nursing and Midwifery Students", American Journal of Nursing Research, 3(2), 36-40, 2015. [13]. Şen M.A., Ceylan A., Kurt, ME., Planacı, Y, Adın, C., "Healthy Lifestyle Behaviours and Effecting Factors of Health Services Vocational College Students", Dicle Medicine faculty/Dicle Medical Journal, 44 (1), 1-11, 2017.

[14]. Cihangiroglu, Z, Deveci, SE., "Healthy Lifestyle Behaviours and Related Influencing Factors of the Students of Elazig High School of Health Sciences of Firat University", Firat Medical Journal, 16(2), 78-83, 2011.

[15] Güner Coşkun İ., Demir F., "Determination of Healthy Lifestyle Behaviours (HLSB) of Surgery Room Nurses", Atatürk University School of Nursery Journal, 9(3), 17-25, 2006.

[16]. Akça, AŞ, Investigation of Health Improving Behaviours and Effecting Factors of University Academicians, Master Thesis, Ege University, Health Science Institute, İzmir. 1998.

[17]. Akgül Gündoğdu, N., Güler, G., "Healthy Lifestyle Behaviors and Self-Efficacy Levels of Health Care Professionals Working at Primary Health Care Institutions". See discussions, stats, and author profiles for this publication at: https://www.researchgate.net/publication/305433655

[18]. Zaybak, A., Fadıloğlu, Ç., "Determination of Health Improving Behaviours and Effecting Factors of University Students”, Ege University Journal of School of Nursery, 20 (1), 71-95.2004.

[19]. Sönmez Benli S., Yıldırım A., "Relationship between Nurses' Life Satisfaction and Attitudes towards Death", Gümüşhane University Journal of Health Sciences, 6(4), 167-179, 2017

[20]. Acheson, D., Alleyne, G. A., Casas, J. A., Castillo-Salgado, C., Barzach, M., Braveman, P., et al., "Round table discussion. Health inequalities and the health of the poor", Bulletin of the World Health Organization, 78(1), 75-85, 2000.

[21]. Esin, M.N. Determination of Health Behaviours of Workers Labouring in Industry Field. Unpublished Master Thesis, İstanbul University, Medicine Faculty, Public Health Department, İstanbul, Turkey. (1997). 